\title{
Proces wymiany waluty narodowej na euro w państwach zabiegających o wejście do III etapu unii gospodarczej i walutowej
}

https://doi.org/10.25312/2391-5129.29/2019_04dk

\begin{abstract}
Publikacja w obszerny sposób charakteryzuje proces powstawania Unii Europejskiej oraz wspólnego obszaru gospodarczego i walutowego poprzez przytoczenie najważniejszych zdaniem autora kroków milowych służących integracji pomiędzy krajami po II wojnie światowej, rozpoczynając od przemówienia W. Churchilla wygłoszonego późnym latem 1946 roku, w którym przedstawił on wizję Stanów Zjednoczonych Europy, do początku XXI wieku, kiedy euro oficjalnie zaczęło zastępować waluty krajowe. Autor przytacza współcześnie obowiązujące kryteria konwergencji oraz skupia się na wyjaśnieniu pojęć ekonomicznych niezbędnych do zrozumienia problematyki zawartej w tytule. Publikacja kończy się opisem procesu zastępowania walut narodowych w trzech największych gospodarkach należących do strefy euro: w Niemczech, we Francji i we Włoszech. W artykule zawarto liczne odwołania do traktatów założycielskich, aktów prawnych Unii Europejskiej czy też wyroków Trybunałów.
\end{abstract}

Słowa kluczowe: kryteria konwergencji, unia gospodarczo-walutowa, zmiana waluty, finanse

\section{Wprowadzenie}

Historia ludzkości, a w niej chęć stworzenia gospodarki rynkowej opartej początkowo na wymianie dóbr materialnych jako podstawowym środku płatniczym przyczyniła się znacząco do stworzenia reguł i tez stanowiących dziś fundament nauk ekonomicznych. Obecnie, dzięki ewolucji cywilizacji i zmiany jej preferencji, niemal całkowicie wyparte zostały wspomniane transakcje barterowe, a w ich miejsce

* Damian Kociemba - student kierunku transport, Wydział Informatyki, Zarządzania i Transportu, Akademia Humanistyczno-Ekonomiczna w Łodzi. 
na stałe pojawił się pieniądz fiducjarny (ang. fiat money) używany przez większość społeczeństwa. Ów pieniądz, którego nazwa pochodzi od łacińskiego słowa fides oznaczającego wiarę i zgodnie z definicją podawaną przez Narodowy Bank Polski, będącego jedynym prawnym emitentem na terenie Polski, jest: „walutą niemającą oparcia w dobrach materialnych (jak na przykład kruszce), której wartość ma źródło $\mathrm{z}$ reguły w dekretowanym prawnie monopolu w wykorzystaniu go na danym obszarze jako legalny środek płatniczy oraz popycie generowanym przez instytucje państwowe, głównie przez pobór podatków. Wartość pieniądza fiducjarnego opiera się na zaufaniu do emitenta" (Krzemień, 2018). Każdy niezależny kraj w ciągu historii swojego istnienia stworzył własny system monetarny. Występujące pomiędzy państwami transakcje powodowały konieczność tworzenia przeliczników zmienianych na podstawie przykładowo aktualnej sytuacji politycznej, co bez wątpienia zmieniało stosunki dyplomatyczne i odbijało się niekorzystnie na wszystkich gospodarkach. Powoli postępująca stabilizacja poglądów wielu krajów, widoczna szczególnie pod koniec XX wieku, oraz chęć zacieśniania współpracy pomiędzy nimi wpłynęły na konieczność stworzenia wspólnej i stabilnej waluty. Ogólny zarys tej idei został spisany w 1995 roku w dokumencie nazywanym scenariuszem madryckim i kilku innych aktach prawnych Unii Europejskiej. Określają one sposób zmiany waluty na euro - używanej obecnie w dziewiętnastu krajach członkowskich.

Celem niniejszego artykułu jest wyjaśnienie wybranych pojęć ekonomicznych niezbędnych do zrozumienia problematyki zawartej w tytule, przybliżenie historii Unii Europejskiej, genezy wspólnego środka płatniczego i jego stopniowej ewolucji wraz z przedstawieniem sposobów zmian waluty na przykładzie trzech państw strefy euro, wśród których wymienić można: Niemcy, Francję oraz Włochy. Kryterium decydującym o wyborze tych gospodarek był ich największy w 2018 roku wkład w tworzenie produktu krajowego brutto $\left(\mathrm{PKB}^{1}\right.$ ) Unii Europejskiej (Gross domestic product at market prices, 2018). Metodą badawczą, jaką autor posłużył się podczas tworzenia artykułu, była analiza i krytyka dostępnego piśmiennictwa.

\section{Geneza i historia Unii Europejskiej}

Proces powstawania Unii Europejskiej znanej w obecnym kształcie nie był łatwy, a początki jej powstania przypadają na okres po II wojnie światowej, zakończonej 2 września 1945 roku. Koncepcja utworzenia Stanów Zjednoczonych Europy zaprezentowana została przez byłego premiera Wielkiej Brytanii Winstona Churchilla (1874-1965) w przemówieniu wygłoszonym 19 września 1946 roku. Zgodnie

\footnotetext{
${ }^{1}$ Najważniejszy i jednocześnie najpopularniejszy wskaźnik, którego zadaniem jest odzwierciedlenie wartości wszystkich wytworzonych w określonej gospodarce dóbr materialnych i niematerialnych w mierzonym okresie czasu wynoszącym zazwyczaj rok. Jedynym kryterium niezbędnym do wyliczenia tego wskaźnika jest miejsce wytworzenia dóbr, nie jest przy tym ważny kapitał przedsiębiorstwa produkcyjnego lub usługowego (Wyżnikiewicz, 2017: 1).
} 
z jego wyobrażeniem działalność organizacji utworzonej przez Francję i Republikę Federalną Niemiec, RFN (bez Narodowej Republiki Demokratycznej, NRD) miała koncentrować się na współpracy wielopłaszczyznowej, prowadząc tym samym do stworzenia przeciwwagi dla ideologii komunistycznej oraz całego bloku wschodniego. Idea Churchilla niewątpliwie była modyfikacją koncepcji Międzynarodowej Unii Paneuropejskiej, którą w okresie międzywojennym przedstawił austriacki dyplomata Richard Coudenhove-Kalergi (1894-1972). Punktem wyjścia Paneuropy było podzielenie świata na cztery zasadnicze regiony, wśród których można wyróżnić: Europę (bez ówcześnie istniejącego Związku Socjalistycznych Republik Radzieckich oraz Wielkiej Brytanii), Amerykę, Związek Socjalistycznych Republik Radzieckich oraz Daleki Wschód. Coudenhove-Kalergi podobnie jak Churchill nie bez powodu umieścił Francję i Niemcy w jednej grupie - jego celem było zażegnanie istniejącego wówczas konfliktu między przedstawicielstwami tych państw, czego końcowym efektem miało być nawiązanie współpracy wielowymiarowej. Twórca tej idei świadom był istnienia elementu istotnie zacieśniającego współpracę międzynarodową konieczności stworzenia jednej, europejskiej kultury. Nie negował przy tym odmienności językowych pomiędzy krajami. Wręcz przeciwnie - podkreślał to jako zaletę, na co zwróciła uwagę Katarzyna Pabis (2013: 10), pisząc „,[...] jednolite politycznie i gospodarczo, zróżnicowane zaś wewnętrznie".

W 1947 roku na mocy podpisanych porozumień powstaje unia celna pomiędzy Belgią, Holandią i Luksemburgiem. Traktat ustanawiający zawierał zapis o jego obowiązywaniu przez 10 kolejnych lat. Ze względu na jego pozytywne skutki dla wszystkich gospodarek, rządy 11 lat później zdecydowały się odświeżyć ten dokument. Odtąd nadana została mu nazwa Układ w sprawie utworzenia Unii Ekonomicznej Beneluksu. Nazwa Beneluks (niderl. Benelux) pochodzi od pierwszych sylab wcześniej wymienionych Królestw oraz Księstwa połączonych w całość (Pabis, 2013: 11). Traktat zaczął obowiązywać od 1960 roku i zgodnie z założeniami miał obowiązywać przez następne 50 lat. Przewidywał rozszerzenie porozumienia celnego, docelowo tworząc pełną unię gospodarczą z wolnym przepływem dóbr materialnych, niematerialnych, kapitału oraz osób. Zakładał także rozszerzenie współpracy w obszarze kształtowania polityki zagranicznej prowadzącej do ujednolicenia taryf handlowych, kontyngentów oraz polityki wizowej. Aby była możliwa realizacja tych postanowień, na mocy traktatu stworzone zostały organy Unii Gospodarczej, wśród których wymienić można (Kołek, 2011: 441):

- Komitet Ministrów (KM) składający się z przedstawicieli oddelegowanych przez państwa będące stronami porozumienia; głównym jego zadaniem było podejmowanie jednomyślnych decyzji;

- 7 komisji i 5 komisji specjalnych będących w założeniu organami o charakterze roboczym; miały za zadanie przedstawianie Komitetowi raportów na temat funkcjonowania danych obszarów tematycznych; liczba komisji mogła być modyfikowana zgodnie z potrzebami; 
- Rada Unii Gospodarczej składająca się z przedstawicieli komisji; główny organ wykonawczy, mający na celu koordynację i czuwanie nad przebiegiem prac komisji oraz sporządzanie dokumentów dla KM o charakterze sugestywnym,

- Międzyparlamentarna Rada Doradcza;

- Ekonomiczno-Społeczna Rada Doradcza - instytucja o charakterze doradczym;

- Kolegium Arbitrów.

W 1965 roku powołany został Trybunał Sprawiedliwości Beneluksu z siedzibą w Brukseli, który rozpoczął swoje funkcjonowanie z początkiem 1974 roku. Jego celem było wydawanie interpretacji poszczególnych porozumień i rozwiązywanie na ich podstawie sporów (Kołek, 2011: 441).

W 1947 roku ówczesny sekretarz Stanów Zjednoczonych Ameryki George Marshall (1880-1959) ogłasza Europejski program naprawczy (ang. European Recovery Program). Od samego początku szerzej znany pod nazwą planu Marshalla (Pabis, 2013: 8, 11, 12). Zakładał udzielenie pomocy finansowej krajom dotkniętym skutkami wojny. Pieniądze zostały wykorzystane między innymi w następujących kwestiach (Pabis, 2013: 12; Madej, 2007: 135):

- stymulacja gospodarcza, której głównym celem było zwiększenie i koordynowanie współpracy narodowej krajów europejskich,

- pomoc socjalna polegająca na wykorzystaniu środków pieniężnych przez kraj beneficjenta w celu wyrównania dysproporcji w poziomie życia mieszkańców,

- spłata zobowiązań finansowych zaciągniętych podczas wojny wobec swoich wierzycieli (w przypadku Wielkiej Brytanii),

- rozwój przemysłu krajowego (Francja).

Ze względu na konieczność nadzorowania procesu rozporządzania otrzymanych przez kraje środków finansowych powołana została do życia w 1948 roku Europejska Organizacja Współpracy Gospodarczej. Skład jej był następujący: Austria, Belgia, Francja, Holandia, Grecja, Hiszpania, Irlandia, Islandia, Luksemburg, RFN, Norwegia, Portugalia, Szwecja, Szwajcaria, Turcja, Wielka Brytania, Włochy. Oprócz tego wspomniane już kraje Beneluksu podpisują porozumienie o współpracy militarnej z Francją i Wielką Brytanią nazywane odtąd paktem brukselskim (Pabis, 2013: 12). Towarzyszący temu optymizm i entuzjazm przywódców spowodował również powstanie w 1948 roku planów zinstytucjonalizowania współpracy na płaszczyźnie politycznej, czego skutkiem było ustanowienie komisji konsultacyjnej zajmującej się kreowaniem polityki zagranicznej cztery lata później. Pomimo ambitnych planów funkcjonalnych oraz powierzonych jej funkcji, pozostała organem o marginalnym znaczeniu (Kołek, 2011: 442). Rok 1960 był rokiem, kiedy pomoc finansowa Stanów Zjednoczonych Ameryki dobiegła końca, jednakże działalność stworzonej instytucji nie została zaprzestana. Zmieniona została jej nazwa na Organizację Współpracy i Rozwoju Gospodarczego. Odtąd głównym jej zadaniem była liberalizacja wymiany towarowej między krajami zainteresowanymi współpracą czy też podejmowanie działań sprzyjających wykorzystaniu atomu w produkcji energii. Pod koniec XX wieku do jej struktur należało 28 krajów (Pabis, 2013: 12). 
Kolejnym krokiem milowym wpływającym na kształt dzisiejszej Unii Europejskiej było stworzenie Kongresu Europejskiego w 1949 roku. Współcześnie znany jest on pod nazwą Rady Europy i zrzesza 47 państw. Celem organu sprecyzowanym w art. 1a Statutu Rady Europy (Dz. U. 1994, nr 118, poz. 565) jest „,[...] osiągnięcie większej jedności między jej członkami, aby chronić i wcielać w życie ideały i zasady stanowiące ich wspólne dziedzictwo, oraz aby ułatwić ich postęp ekonomiczny i społeczny". Ponadto powołana została do życia Organizacja Paktu Północnego Atlantyku, znana szerzej pod skrótem NATO. Zgodnie $\mathrm{z}$ informacjami zawartymi w preambule sporządzonej z tej okazji umowy ratyfikowanej przez Polskę w 1999 roku „strony [...] są zdecydowane ochraniać wolność, wspólne dziedzictwo i cywilizację swych narodów, oparte na zasadach demokracji, wolności jednostki i rządów prawa. [...] Są zdecydowane połączyć swe wysiłki w celu zbiorowej obrony oraz zachowania pokoju i bezpieczeństwa [...]". Oprócz tego art. 5 niniejszej umowy zawiera bardzo ważny z punktu widzenia bezpieczeństwa zapis: „Strony zgadzają się, że zbrojna napaść na jedną lub więcej z nich w Europie lub Ameryce Północnej będzie uznana za napaść przeciwko nim wszystkim [...]” (Dz. U. 2000, nr 87, poz. 970).

Intensyfikacja działań podejmowanych przez polityków tamtejszej sceny doprowadziła do zaprezentowania w 1950 roku przez ministra spraw zagranicznych Francji Roberta Schumana (1886-1963) koncepcji Jeana Monneta (1888-1979), Paula Reutera (1911-1990), Pierre'a Uri (1911-1992) i Étienne’a Hirscha (1901-1994). Ich pomysł opierał się na podjęciu szeroko rozumianej współpracy gospodarczej sprzyjającej budowie jednolitego organizmu. Całość rozpoczęła się od podpisania rok później dokumentu tworzącego Europejską Wspólnotę Węgla i Stali (EWWiS). W jej skład wchodziły: Belgia, Francja, Holandia, Luksemburg, Republika Federalna Niemiec, Włochy. Idea planu opierała się na międzynarodowej kontroli procesów produkcyjnych, co było punktem integracji Europy minimalizując tym samym przyszłe niebezpieczeństwa militarne oraz gospodarcze. W 1953 roku utworzono wspólny rynek węgla, rud żelaznych, złomu i stali. Powołanie EWWiS przyczyniło się do stworzenia koncepcji innych organizacji (Pabis, 2013: 13, 14; Historia: Europejska Wspólnota Obronna, 2011):

- Europejskiej Wspólnoty Obronnej (EWO) mającej charakter militarny. Jej działanie miało skupić się na obronie państw członkowskich. Funkcjonowanie zostało zapoczątkowane w 1952 roku traktatem paryskim. Sygnatariuszami zostały kraje EWWiS. Późniejsze obawy francuskiego parlamentu dotyczące zasadności militaryzacji RFN skutkowały wycofaniem ratyfikacji. Koncepcja ta ponownie została przywołana w Traktacie o Unii Europejskiej (TUE) przyjętym w Maastricht (Dz. Urz. UE C 326/13 z 26.10.2012 r.). Na podstawie TUE utworzona została Wspólna polityka bezpieczeństwa i obrony. Celem jej jest wspieranie rozwoju sił wojskowych oraz cywilnych UE. Program tej organizacji jest kompatybilny z ideami NATO, ponieważ skupia się na zarządzaniu kryzysowym, zapobieganiu konfliktom, misjom humanitarnym, ewakuacji ludności z terenów objętych wojną, utrzymywaniu pokoju i tym podobnych. 
- Europejskiej Wspólnoty Politycznej (EWP) mającej zapewnić kontrolę nad niezależnym powstaniem i funkcjonowaniem EWO, a w późniejszym czasie powiązanie jej z EWWiS. Ze względu na sceptycyzm i obawy Francji organizacja ta nie została powołana.

Niestrudzeni wypowiedzeniem ratyfikacji Francji członkowie EWWiS rozpoczęli przygotowania krajów Europy do współpracy na płaszczyźnie ekonomicznej, zaczynając od rozszerzenia integracji w sektorze energetycznym i transportowym. Lata pertraktacji skończyły się podpisaniem w 1957 roku w Rzymie traktatu o utworzeniu Europejskiej Wspólnoty Gospodarczej (EWG) oraz Europejskiej Wspólnoty Energii Atomowej (EWA, także Euratom). Dwa podmioty przejęły konstrukcje wypracowane przez EWWiS (Pabis, 2013: 13-17). Dzięki odpowiednim krokom podjętym przez państwa Beneluksu podczas tworzenia EWG traktaty zagwarantowały istnienie organizacji ponadnarodowych, mających wspomagać zabezpieczenie interesów bardziej obiektywnie w porównaniu z międzynarodowymi, gdzie istniałoby ryzyko posiadania głosu decydującego przez gospodarki większe i prężniejsze (Kołek, 2011: 443).

W 1968 roku została utworzona jednolita taryfa celna dla państw zewnętrznych oraz nastąpiło zniesienie ceł pomiędzy nimi. Podjęto działania wspierające przepływ pracowników i usług. Rok 1967 przyniósł konieczność dokonania poprawek w sferze organizacyjnej - przyjęty został tzw. traktat fuzyjny. Odtąd ustanowiona została jedna Rada oraz Komisja dla wszystkich stworzonych Wspólnot Europejskich. Po tych wydarzeniach nastąpiło spowolnienie procesu rozwoju. Nabrał on ponownie rozpędu pomiędzy latami 70. a 90. XX wieku głównie za sprawą rozszerzenia Unii o kolejne kraje. Do UE przystąpiły: Dania, Grecja, Hiszpania, Irlandia, Portugalia i Wielka Brytania. Oprócz tego zwiększono kompetencje Wspólnoty. Coraz częściej zaczęto mówić o potrzebie stworzenia Europejskiego Banku Centralnego ze względu na problemy finansowe rolnictwa. Rozłam bloku państw socjalistycznych oraz zjednoczenie RFN z NRD, czego efektem było powstanie Republiki Federalnej Niemiec, zaowocowało koniecznością odrodzenia i ponownego zastosowania procesów integracyjnych. W 1992 roku przyjęto w Maastricht Traktat o Unii Europejskiej (Pabis, 2013: 13-17). Na jego mocy 1 listopada 1993 roku oficjalnie powstała Wspólnota Europejska. Traktat ten proponował tak zwaną konstrukcję trójfilarową (Traktat z Maastricht i traktat z Amsterdamu, 2019: 12), na którą składał się:

- Filar pierwszy (Wspólnota Europejska) - odtąd obowiązkiem wspólnoty było zapewnienie prawidłowego funkcjonowania jednolitego rynku rozwijającego się trwale, harmonijnie i zrównoważenie, przy możliwie jak najwyższym poziomie zatrudnienia i ochrony socjalnej. Zagwarantowane w nim zostało stworzenie wspólnej waluty.

- Filar drugi (wspólna polityka zagraniczna i bezpieczeństwa) - współpraca międzyrządowa państw członkowskich ma się opierać na ochronie wspólnych wartości, interesów, niezależności i integralności UE.

- Filar trzeci (współpraca w dziedzinie wymiaru sprawiedliwości i spraw wewnętrznych) - działania państw członkowskich mają gwarantować wysoki 
poziom ochrony, wolności oraz sprawiedliwości między innymi poprzez podejmowanie odpowiednich kroków służących zwalczaniu terroryzmu, przestępczości, handlu narkotykami czy też współpracy pomiędzy wymiarami sprawiedliwości.

Filary te funkcjonowały do czasu przyjęcia podpisanego w 2007 roku traktatu lizbońskiego zmieniającego nazwę na Unię Europejską. Nabrał on mocy prawnej dwa lata później i znacząco rozszerzył kompetencje UE, znanej współcześnie i zrzeszającej 28 krajów.

\section{Warunki przystapienia do Unii Europejskiej}

Warunki przystąpienia jakiegokolwiek kraju do Unii Europejskiej reguluje art. 49 Traktatu o Unii Europejskiej, którego brzmienie jest następujące: „Każde państwo europejskie, które szanuje wartości, o których mowa w artykule 2, i zobowiązuje się je wspierać, może złożyć wniosek o członkostwo w Unii [...]”. Natomiast wspomniany art. 2 mówi: „Unia opiera się na wartościach poszanowania godności osoby ludzkiej, wolności, demokracji, równości, państwa prawnego, jak również poszanowania praw człowieka, w tym praw osób należących do mniejszości. Wartości te są wspólne Państwom Członkowskim w społeczeństwie opartym na pluralizmie, niedyskryminacji, tolerancji, sprawiedliwości, solidarności oraz na równości kobiet i mężczyzn”. Oprócz spełnienia powyższych norm należy wypełnić szereg tak zwanych kryteriów kopenhaskich ustalonych przez Radę Europejską w 1993 roku i zmodyfikowanych w 1995 roku podczas zjazdu madryckiego. Wśród nich wyróżnić można (Barcz, 2009: 87-88; Breński, 2013: 7; Traktat z Maastricht $i$ traktat z Amsterdamu, 2019: 1-2):

- stabilność instytucji odpowiedzialnych za zapewnienie demokracji, praworządności, ochrony praw człowieka z uwzględnieniem mniejszości (spełnienie tego kryterium otwiera możliwość negocjacji z UE),

- sprawnie funkcjonującą gospodarkę rynkową, która podoła konkurencji panującej wewnątrz całej UE oraz będzie wywiązywać się z zobowiązań akcesyjnych,

- zdolność samej Unii Europejskiej do przyjmowania nowych państw członkowskich,

- przyjęcie całego dorobku prawnego Wspólnot Europejskich (fr. acquis communautaire). Nakłada to obowiązek respektowania traktatów założycielskich, Jednolitego aktu europejskiego, Traktatu o Unii Europejskiej z późniejszymi zmianami, ustawodawstwa wykonawczego wszystkich aktów prawnych, orzecznictwa Trybunału Sprawiedliwości i Sądu Pierwszej Instancji, umów międzynarodowych Unii, rozporządzeń, dyrektyw, decyzji, aktów wewnętrznych oraz aktów nienazwanych typu oświadczenia, rezolucje, komunikaty i tym podobne. 
Niezbędne jest również spełnienie warunku będącego wynikiem orzecznictwa Trybunału Sprawiedliwości Unii Europejskiej - zaakceptowanie nadrzędności prawa unijnego nad prawem krajowym². Dzięki temu sądy państw UE zyskały możliwość zastosowania regulacji wspólnotowych w przypadku sprzeczności z nimi przepisów krajowych. Ponadto ustawodawca zobowiązany jest do zakazu stanowienia i uchylania ustaw niezgodnych z unijnymi normami. Takie działanie ma zagwarantować jednolitość prawa we wszystkich państwach członkowskich (Breński, 2013: 87, 88). Zasada ta była przedmiotem analizy Trybunału Konstytucyjnego, który wyraził swoje stanowisko wyrokiem o sygn. K 18/04 z dnia 11 maja 2005 roku (Dz. U. 2005, nr 86, poz. 744), opowiadając się jednoznacznie za pierwszeństwem obowiązywania i nadrzędnością Konstytucji Rzeczpospolitej Polskiej ze względu na zamieszczony tam art. 8 ust. $1 \mathrm{w}$ następującym brzmieniu: „Konstytucja jest najwyższym prawem Rzeczypospolitej Polskiej” (Dz. U. 1997, nr 78, poz. 483 z późniejszymi zmianami). Pomimo to Trybunał podkreślił niezbędność koegzystencji pomiędzy tymi dwoma centrami prawodawczymi.

\section{Geneza i historia powstania unii gospodarczej i walutowej}

W latach 40. XX wieku nie istniała jeszcze koncepcja utworzenia wspólnej waluty europejskiej ze względu na sprawnie funkcjonujący system o nazwie Bretton Woods. Mechanizm ten bazował na powiązaniu złota z dolarem amerykańskim. Podczas prac przygotowawczych służących wprowadzeniu niniejszego rozwiązania, które zakończone zostały w 1944 roku, określona została sztywna wartość jednego dolara jako równowartość $1 / 35$ uncji złota. Uprawnienia wymiany na podstawie powyższego przelicznika przysługiwały jedynie rządom krajowym oraz ich bankom centralnym. Organizacje te zostały zobowiązane do stworzenia i prowadzenia polityki monetarnej skutkującej tym, aby wahania kursów między walutami były mniejsze bądź równe $1 \%$. Takie działanie miało zapewnić gospodarkom pieniądz o stałej wartości. W celu kontroli całego procesu i wykrywania nieprawidłowości powołany został Bank Odbudowy i Rozwoju (znany dziś jako Bank Światowy) oraz Międzynarodowy Fundusz

\footnotetext{
${ }^{2}$ Wyrok z dnia 15 lipca 1964 roku w sprawie C-6/64 pomiędzy Flaminio Costa a E.N.E.L., gdzie Trybunał Sprawiedliwości Unii Europejskiej stwierdził: „,...] zważywszy, że w związku $\mathrm{z}$ włączeniem do prawa każdego z krajów członkowskich przepisów pochodzenia wspólnotowego, a bardziej ogólnie ze względu zarówno na brzmienie, jak ducha traktatu, państwa nie mogą uznawać pierwszeństwa przed porządkiem prawnym, jaki przyjęły na zasadach wzajemności, jednostronnego, późniejszego przepisu, którego w związku z tym nie mogą temu porządkowi prawnemu przeciwstawiać”. Oprócz tego przyjęty traktat z Lizbony (2007) zmieniający Traktat o Unii Europejskiej i Traktat ustanawiający Wspólnotę Europejską zawiera deklarację nr 17 odnoszącą się do pierwszeństwa. Zawarty w niej został następujący zapis: „Konferencja przypomina, że zgodnie z utrwalonym orzecznictwem Trybunału Sprawiedliwości Unii Europejskiej Traktaty i prawo przyjęte przez Unię na podstawie Traktatów mają pierwszeństwo przed prawem Państw Członkowskich na warunkach ustanowionych przez wspomniane orzecznictwo" (Dz. Urz. UE C 306 z 17.12.2007 r.).
} 
Walutowy (Gwóźdź-Lasoń, Miklaszewicz, Pujer, 2017: 14). Utrzymywanie kursów walut na żądanym pułapie było kwestią problematyczną, stąd konieczność częstych interwencji banków centralnych. Zawarte później porozumienia zmieniły pasmo dopuszczalnych oscylacji do 2,25\%. Stworzone rozwiązanie spełniało swoją funkcję do 1971 roku, po czym zostało zawieszone przez 37. prezydenta Stanów Zjednoczonych Ameryki Richarda Nixona (1913-1994). Powodem takiego kroku był stale zwiększający się popyt na amerykańską walutę, której ilość przestała mieć pokrycie w kruszcu. Dzięki temu w ciągu kilku lat dokonano dewaluacji, czyli osłabienia sztywnego kursu walut za pomocą narzędzi prawnych (wprowadzanie ustaw lub wydawanie decyzji administracyjnych) oraz upłynnienia kursu ${ }^{3}$ dolara. Oznaczało to początek tzw. systemu wielodewizowego ${ }^{4}$ używanego współcześnie. Występująca w latach 70. XX wieku niestabilność między kursami walut, działania podjęte przez Nixona, wysoka inflacja czy też wygłoszenie przez przewodniczącego Komisji Roya Jenkinsa (1920-2003) w 1977 roku przemowy, w której podkreślił konieczność zwiększenia integracji wewnątrzeuropejskiej poprzez podjęcie działań zmierzających do utworzenia wspólnej waluty, wpłynęły na przyspieszenie prac sprzyjających stworzeniu Europejskiego Systemu Monetarnego (ESM). Swoje funkcjonowanie rozpoczął 13 marca 1979 roku i oparty został (podobnie jak WE) na trzech filarach (Sofuł, 2009; Gwóźdź-Lasoń, Miklaszewicz, Pujer, 2017: 18; Szopa, 2012: 28):

- Filar pierwszy - Europejska Jednostka Walutowa, EJW (ang. European currency unit, ECU) składająca się początkowo z koszyka 9 walut (później liczba ta została zwiększona o 3) krajów WE. Waga każdej zależna była od stopnia zaangażowania danego kraju w handel wewnątrzunijny i produktu krajowego brutto (PKB) całej wspólnoty. Wzajemne powiązanie walut ESM z ECU pozwoliło całkowicie uniezależnić się od popularnego wówczas dolara amerykańskiego. Powstała tym sposobem jednostka niebędąca walutą, wykorzystywana była w kalkulacjach i operacjach dokonywanych przez banki. Poprawne

${ }^{3}$ W systemie kursów płynnych cena waluty determinowana jest przez popyt oraz podaż. Zwykle wdrażany jest przez gospodarki ustabilizowane i otwarte. Cechą główną tego mechanizmu jest całkowita niezależność banku centralnego w prowadzeniu polityki pieniężnej gospodarki, ograniczając tym samym możliwość wystąpienia nacisków politycznych. System ten dzieli się zasadniczo na dwie grupy (Gajewski, Pilichowska, 2016: 203): 1. Kurs całkowicie płynny uzależniony w całości od działających sił rynkowych. Jego aktualny kurs nie podlega ingerencji ze strony Banku Centralnego lub rządu. 2. Kurs kierowany płynny zależny od popytu i podaży z tą różnicą, że podmioty gospodarcze mogą liczyć na interwencję ze strony Banku Centralnego.

${ }^{4}$ Wbrew pozorom jego istnienie nie zostało zapoczątkowane dyskusjami przywódców krajowych, lecz powstał ze względu na podejmowanie indywidualnych działań na płaszczyźnie kształtowania własnej polityki kursowej (wykorzystanie kursu walutowego tak, aby osiągnąć główne cele gospodarki). Współcześnie walutami posiadającymi status pieniądza międzynarodowego są: funt brytyjski, frank szwajcarski, jen czy też euro (Mikita, 2016: 89). Wśród głównych przyczyn stworzenia tego systemu można wyróżnić chęć uniezależnienia się od waluty amerykańskiej, zakończenie stworzonego przez nią monopolu, jak i chęć osiągnięcia stabilności gospodarek, ponieważ gromadzenie rezerw w kilku walutach sprawia, że wahania kursów nie podlegają kumulowaniu, powodując tym samym mniejsze straty. 
działanie stworzonego systemu zostało zaburzone z końcem lat 70. XX wieku ze względu na wystąpienie kryzysu przemysłu naftowego. Konsekwencją było porzucenie wizji przeniesienia rezerw złota i dewiz z banków centralnych Europejskiego Systemu Walutowego do stworzonego Europejskiego Instytutu Walutowego w zamierzeniu mającego być reprezentantem interesów ich wszystkich na arenie międzynarodowej podczas prowadzenia rozmów z Japonią oraz Stanami Zjednoczonymi Ameryki. Te negocjacje miały przyczynić się do utworzenia Międzynarodowego Systemu Walutowego, MSW (ang. International Monetary System, IMS). Program ten nie został ukończony.

- Filar drugi - mechanizm kursu walutowego (ang. Exchange Rate Mechanism, ERM) polegający na utrzymywaniu kursów walut w określonym przedziale wahań. Głównym celem systemu było zapobieganie sytuacjom, gdzie mogą wystąpić nadmierne wahania (spowodowane na przykład atakiem spekulacyjnym ${ }^{5}$ ) osłabiające bądź umacniające walutę narodową, poprzez wyznaczenie jej centralnego kursu oraz dopuszczalnych wahań wokół niego. W 1993 roku recesja gospodarcza i panujący wówczas kryzys spowodowały zmianę pasma dopuszczalnych fluktuacji $\mathrm{z} \pm 2,25 \%$ na maksymalnie $\pm 15 \%$, pozostawiając tym samym szeroki korytarz negocjacji. Aktualnie program od 1999 roku wykorzystywany jest przez Danię, która pomimo zagwarantowania w traktacie akcesyjnym braku konieczności przyjmowania euro zdecydowała się na taki krok, motywując go chęcią ustabilizowania kursu swojej waluty, określając przy tym pasmo wahań na $\pm 2,25 \%$.

- Filar trzeci - system pomocy kredytowej skierowany do banków centralnych walut słabszych w celu podjęcia działań stabilizujących kursy swoich walut.

ESM zakończył swoje funkcjonowanie z końcem 1998 roku. Wtedy też powstała waluta euro, zastępując EJW w relacji 1:1 (Szopa, 2012: 33).

Równolegle z działaniami podejmowanymi na rzecz Europejskiego Systemu Monetarnego 12 ówczesnych państw członkowskich zdecydowało o podjęciu starań prowadzących do spełnienia wizji unii gospodarczej i walutowej (UGW). Pierwszym krokiem sprzyjającym realizacji tego celu było zobowiązanie przez Radę Europejską komitetu kierowanego przez Jacquesa Delorsa (1925), będącego ówczesnym przewodniczącym Komisji Europejskiej, do przedstawienia możliwych opcji. Rok później opublikował on plan (nazywany planem Delorsa) stanowiący zestaw trzech niezbędnych etapów (Scheller, 2006: 22):

${ }^{5}$ Działanie polegające na masowej sprzedaży uprzednio zakupionej w dużej ilości waluty, zwykle takiej, której tendencja na rynku od dłuższego czasu jest spadkowa. Następstwem tego jest gwałtowny i postępujący spadek wartości, wskutek czego następuje utrata zaufania do niej. Gdy kurs znajduje się na zadowalająco niskim dla spekulantów poziomie, następuje jej odkupienie po zaniżonej cenie, spłacenie swoich zobowiązań, zarabiając przy tym na różnicy w kursach (Piński, 2016). 
- etap I polegający na usunięciu wszystkich przeszkód utrudniających integrację finansową i walutową, to znaczy ustalenie jednej polityki gospodarczej, jak i utworzenie silnego i konkurencyjnego rynku wewnętrznego,

- etap II ustanawiający niezbędne instytucje i ich struktury organizacyjne, wzmacniające tym samym konwergencję gospodarczą (co miało zwiększyć permanentność etapu I),

- etap III polegający na ustanowieniu nieodwołalnych kursów walut.

Oprócz tego podczas realizacji ostatniego kroku miało nastąpić przekazanie pełnych kompetencji pieniężnych i gospodarczych uprzednio stworzonym instytucjom. Podczas trwania tego etapu miał zostać zapoczątkowany proces sukcesywnego zastępowania walut narodowych.

Realizacja planu Delorsa rozpoczęła się w 1990 roku. Z dniem 1 lipca zniesiono zasadniczo wszystkie ograniczenia wpływające na przepływ kapitału pomiędzy krajami członkowskimi. Wszczęte zostały procesy koordynowania polityki pieniężnej prowadzące do stabilizacji cen. Jako że etapy II i III zakładały zwiększoną ingerencję ze strony EWG, niezbędna stała się modyfikacja Traktatu ustanawiającego Wspólnotę. W 1992 roku w miejscowości Maastricht (Holandia) podpisany został traktat powołujący Unię Europejską oraz zmienione zostały traktaty tworzące poszczególne Wspólnoty. Nowa wersja zawierała odtąd rozdziały o polityce pieniężnej i gospodarczej. Zmieniona została nazwa EWG na Wspólnotę Europejską. Do ratyfikowanego przez 12 krajów członkowskich dokumentu załączone zostały protokoły ustanawiające Statuty: Europejskiego Instytutu Walutowego (EIW), Europejskiego Systemu Banków Centralnych ${ }^{6}$ (ESBC) i Europejskiego Banku Centralnego ${ }^{7}$ (EBC). Przedstawicielstwa Danii i Wielkiej Brytanii wynegocjowały warunki zwalniające je z uczestnictwa w trzecim etapie. Dwa lata po tych wydarzeniach, w 1994 roku zdecydowano o rozpoczęciu realizacji etapu II. Stworzony został EIW na podstawie uprzednio przyjętego Statutu. Instytucja ta od samego początku miała tymczasowy charakter. Jej działalność koncentrowała się na przygotowaniu etapu III planu Delorsa między innymi poprzez wykonanie następujących zadań wynikających z art. 117 Traktatu o Unii Europejskiej (Scheller, 2006: 22-23):

- stworzenie procedur oraz niezbędnych instrumentów umożliwiających prowadzenie wspólnej polityki pieniężnej strefy euro,

${ }^{6}$ Powstanie tego organu było spowodowane chęcią stworzenia ogniwa łączącego współpracę pomiędzy Europejskim Bankiem Centralnym a bankami centralnymi wszystkich krajów członkowskich Unii Europejskiej. Głównym jego celem jest utrzymanie stabilności cen (Ciszak i in., 2004: 6).

${ }^{7}$ Cechą odróżniającą Europejski Bank Centralny od banków centralnych krajów jest jego ponadnarodowy charakter (Scheller, 2006: 31). Do głównych zadań Europejskiego Banku Centralnego należy zajmowanie się kreowaniem polityki pieniężnej w strefie euro, przeprowadzanie transakcji dewizowych, utrzymywanie rezerw walutowych lub też umożliwienie funkcjonowania systemów płatniczych. Jest to jedyny organ mający kompetencje do wydawania zezwoleń na emisję euro (Ciszak i in., 2004: 7). 
- stworzenie i rozpowszechnienie metod gromadzenia, komparacji czy dalszej publikacji statystyk sektora finansowego,

- stworzenie i wdrożenie sposobów zarządzania rezerwami oraz prowadzenia operacji walutowych,

- stworzenie specyfikacji banknotów od strony technicznej i projektowej,

- stworzenie i wdrożenie systemów teleinformatycznych niezbędnych ESBC,

- opracowanie nowej procedury ERM II używanej w przyszłości,

- pomoc dla organów europejskich podczas prac nad przepisami wspólnotowymi,

- koordynowanie i monitorowanie postępów państw przyszłej strefy euro.

W 1995 roku podczas madryckiej sesji Rady Europejskiej potwierdzona została realizacja ostatniego etapu UGW, który rozpoczął swoje funkcjonowanie z dniem 1 stycznia 1999 roku

Podczas tego zjazdu utworzony został scenariusz madrycki, który między innymi określił nazwę nowej waluty - euro oraz wydał zalecenie, aby od 1 stycznia 1999 roku został wprowadzony trzyletni okres przejściowy służący uwzględnieniu różnic w tempie przystosowania się do wspólnego środka płatniczego przez społeczeństwo oraz sektory: finansowy, przedsiębiorstw i publiczny. W grudniu 1995 roku Instytut przedstawił swoje zalecenia odnośnie przyszłych działań przygotowujących nowe kraje do przyjęcia euro. Ich praca została uwzględniona przez Radę Europejską w podjętej Uchwale o zasadach i podstawowych elementach nowego mechanizmu kursowego (ERM II). Równocześnie rozpoczęte zostały prace nad przyszłymi relacjami pomiędzy euro a walutami krajów spoza strefy. Oprócz tego ogłoszono konkurs na zaprojektowanie szaty graficznej banknotów i monet, w którym zostały wyłonione zwycięskie projekty autorstwa Belga Luca Luycxa (1958) oraz Austriaka Roberta Kaliny (1955). Belgijski grafik na rewersie monet zaprezentował państwa członkowskie. Awers natomiast podlega personalizacji przez kraj emitenta. Austriacki projektant odpowiedzialny był za przygotowanie banknotów, na których przedstawione zostały konstrukcje architektoniczne typowe dla różnych krajów WE. Wśród nich znaleźć można następujące style: klasyczny (5 EUR), romański (10 EUR), gotycki (20 EUR), renesans (50 EUR), barok i rokoko (100 EUR), architekturę szkła i żelaza oraz styl nowoczesny z XX wieku (200 i 500 EUR). 1 czerwca 1998 roku powołany został prezes, wiceprezes oraz zarząd Europejskiego Banku Centralnego przejmujący kompetencje zlikwidowanego EIW. Na początku 1999 roku ustalono nieodwołalne kursy walut jedenastu państw członkowskich (Grecja jako dwunasta spełniła wszystkie kryteria dopiero pod koniec 2001 roku) oraz powierzono EBC zadania prowadzenia polityki pieniężnej. W tym samym czasie euro zastąpiło wszystkie krajowe waluty, jednakże ze względu na okres przejściowy pomiędzy 1999 a 2001 rokiem państwa mogły zezwolić na rozliczanie należności i zobowiązań z wykorzystaniem nowej waluty albo ustanowionych wcześniej przeliczników. Niektóre instytucje finansowe, takie jak banki, zdecydowały się znacznie wcześniej na przygotowanie swoich klientów do nowej waluty poprzez wyświetlanie stanu konta dwojako (nieodwołalne kursy walut nie zostały zmodyfikowane, a zaczerpnięte z mechanizmu 
kursowego ERM). Wprowadzenie euro zostało zakończone na początku 2002 roku. Pierwszy kwartał tamtego roku został poświęcony działaniom na rzecz ustanowienia euro jedynym prawnym środkiem płatniczym (Scheller, 2006: 22-28).

Współcześnie strefa euro składa się z 19 krajów członkowskich Unii Europejskiej. Od początku jej istnienia do czerwca 2019 roku wydrukowano i wybito łącznie 22806157713 banknotów oraz 132862789307 monet o różnych nominałach (banknotes and coins circulation).

\section{Kryteria konwergencji}

Współcześnie warunki konieczne do spełnienia przez kraj ubiegający się o zmianę waluty narodowej na walutę europejską przedstawia protokół nr $13 \mathrm{w}$ sprawie kryteriów konwergencji (Dz. Urz. UE C 326/281 z 26.10.2012 r.). Protokół ten jest załącznikiem Traktatu o funkcjonowaniu Unii Europejskiej (TfUE) i powstał na podstawie zapisanego w nim art. 140 ust. 1. Zawiera następujące postanowienia:

1. Kryterium stabilności cen - stabilność cen państwa członkowskiego ubiegającego się o przystąpienie do strefy euro musi znajdować się na trwałym poziomie, a średnia stopa inflacji ${ }^{8}$ zmierzona i odnotowana w ciągu jednego roku poprzedzającego badanie musi znajdować się na poziomie nieprzekraczającym o więcej niż 1,5\% inflacji trzech państw członkowskich o najbardziej stabilnych cenach. Wartość ta mierzona jest za pomocą zharmonizowanego wskaźnika cen produkcyjnych oznaczonego skrótem HICP. Wykorzystywany jest on przez wszystkie kraje Unii Europejskiej. Aby było możliwe jego obliczenie, niezbędne jest zgromadzenie informacji o średnich wzrostach bądź spadkach cen różnych dóbr według europejskiej klasyfikacji spożycia indywidualnego według celu (ECOICOP). Owe cele stanowią 12 głównych grup towarów, wśród których wyróżnić można między innymi: żywność i napoje

${ }^{8}$ Najczęściej spotykaną, a zarazem najbardziej ogólną definicją inflacji jest określenie jej jako procesu charakteryzującego się stałym i utrzymującym się w danym mierzonym okresie wzrostem cen oferowanych na rynku dóbr materialnych i niematerialnych. Nie ma więc mowy o inflacji w przypadku skokowej zmiany ceny oferowanego dobra spowodowanej przykładowo zwiększeniem podatków (Grabia, 2007: 547-548). Najbardziej odczuwalnym dla ogółu społeczeństwa skutkiem jest więc spadek wartości pieniądza, który nie może zaspokajać takiej samej ilości potrzeb, jak to robił dotychczas. Pomimo postrzegania tego zjawiska jako negatywne, jest ono czynnikiem stymulującym wiele gospodarek świata. Przykładowo Narodowy Bank Polski realizuje tak zwaną politykę celu inflacyjnego, określając ją na poziomie $2,5 \% \pm 1 \%$, natomiast Europejski Bank Centralny stara się ją utrzymać poniżej, ale blisko 2\% (Żuk, 2015). Jednym z wielu narzędzi stosowanym przez EBC i pomagającym osiągnąć ten cel jest luzowanie ilościowe (ang. quantitative easing, QA), czyli proces dodruku pieniądza oraz obniżki stóp procentowych, po których udzielane są pożyczki bankom komercyjnym. W zastaw dodatkowo brane są obligacje i bony. Dzięki temu wspomniane instytucje świadczące usługi finansowe pozbywają się problemu płynności, ponieważ dysponują większą ilością gotówki przeznaczoną na świadczenie usług swoich klientów. Program ten został wykorzystany pierwszy raz przez EBC na początku 2015 roku (Orłowski, 2015). 
bezalkoholowe; napoje alkoholowe, wyroby tytoniowe i narkotyki; odzież i obuwie; użytkowanie mieszkania lub domu, zaopatrzenie w wodę, energię elektryczną, gaz i inne paliwa; wyposażenie mieszkania lub domu i prowadzenie gospodarstwa domowego; zdrowie; transport; łączność; rekreację i kulturę; edukację; restauracje i hotele; pozostałe towary i usługi (European Classification of Individual Consumption according to Purpose - ECOICOP).

2. Kryterium sytuacji finansów publicznych - w czasie prowadzonego postępowania mającego na celu ustalenie spełnienia wszystkich kryteriów państwo członkowskie nie może być objęte decyzją wydaną przez Radę Unii Europejskiej na podstawie art. 126 ust 1. TfUE stwierdzającą istnienie nadmiernego deficytu (EDP). Procedurę oraz jej wytyczne reguluje protokół nr 12 określający procedurę nadmiernego deficytu. Stanowi on załącznik do TfUE (Dz. Urz. UE C 326/279 z 26.10.2012 r.). Wartości te są następujące: 3\% dla stosunku planowanego lub rzeczywistego publicznego deficytu ${ }^{9}$ komparowanego z produktem krajowym brutto wyrażonym w cenach rynkowych oraz $60 \%$ dla stosunku zadłużenia publicznego ${ }^{10}$ zestawionego z produktem krajowym brutto wyrażonym w cenach rynkowych. Jak wskazują Adrian Grycuk i Piotr Russel (2017: 87), Polska objęta była tą procedurą dwukrotnie - pomiędzy 2004 i 2008 rokiem oraz pomiędzy 2009 i 2015 rokiem.

3. Kryterium udziału w mechanizmie kursów walut Europejskiego Systemu Walutowego (ERM II) - państwo członkowskie zobowiązane jest poruszać się w granicach wahań kursu walutowego bez doprowadzania do napięć na co najmniej 2 lata przed okresem poprzedzającym badanie. Wahania mogą zostać wywołane przykładowo za pomocą procesu dewaluacji. Główny cel i działanie systemu zostało zawarte w podrozdziale Geneza i historia powstania waluty euro.

4. Kryterium konwergencji stóp procentowych - państwo członkowskie powinno posiadać średnią stopę procentową o charakterze nominalnym (umownym) długoterminowym, której wartość nie przekraczała 2\% stopy procentowej w trzech państwach członkowskich o najbardziej stabilnych cenach. Przy ocenie tego kryterium brane są pod uwagę obligacje skarbowe.

${ }^{9}$ Zgodnie $\mathrm{z}$ definicją zamieszczoną w art. 2 protokołu nr 12 tiret pierwszy w sprawie procedury dotyczącej nadmiernego deficytu, stanowiącego załącznik do Traktatu o funkcjonowaniu Unii Europejskiej, publiczny deficyt oznacza zadłużenie ,[...] całej władzy publicznej, czyli rządu centralnego, władz regionalnych lub lokalnych i funduszy ubezpieczeń społecznych, z wyłączeniem operacji handlowych, w rozumieniu Europejskiego Systemu Zintegrowanej Rachunkowości Gospodarczej”.

${ }^{10}$ Zgodnie $\mathrm{z}$ definicją zamieszczoną $\mathrm{w}$ art. 2 protokołu $\mathrm{nr} 12$ tiret drugi w sprawie procedury dotyczącej nadmiernego deficytu, stanowiącego załącznik do Traktatu o funkcjonowaniu Unii Europejskiej, zadłużenie publiczne oznacza ,[...] całkowitą sumę zadłużenia brutto w wartości nominalnej, występującą na koniec roku i skonsolidowaną dla wszystkich sektorów władzy publicznej, zgodnie z definicją zawartą w pierwszym tiret". Zadłużenie brutto wyrażone wartością nominalną oznacza całkowite zadłużenie bez uwzględnienia czynników mogących wpłynąć na zmianę tej wartości (na przykład inflacja). 


\section{Proces wymiany waluty na poziomie narodowym}

Dotychczasowe dokonania 19 spośród 28 krajów członkowskich Unii Europejskiej stworzyły poniekąd niepisane procedury stanowiące wzorzec, który został wykorzystany ostatni raz w 2015 roku na Litwie, kiedy to lit został oficjalnie zastąpiony euro. W całym procesie wyróżnić można kilka kroków prowadzących do sprawnej zmiany waluty. W podrozdziale tym ze względów technicznych proces zastępowania walut został scharakteryzowany tylko dla trzech największych w 2018 roku gospodarek należących do III etapu UGW. Podczas badania głównym kryterium wyboru był największy udział w tworzeniu produktu krajowego brutto Unii Europejskiej. Na tej podstawie wyróżniono (Gross domestic product at market prices, 2018) Niemcy, Francję oraz Włochy. Cały etap dla każdej gospodarki można podzielić na 8 zasadniczych etapów (Przebieg procesu wprowadzania banknotów i monet euro w państwach unii gospodarczej $i$ walutowej, 2003: 9, 63-69, 102-108, 115-120):

1. Określenie nieodwołalnych kursów walut przez Radę:

- Niemcy: wartość 1 EUR odpowiadała 1,95583 DEF (marka niemiecka),

- Francja: zastosowano przelicznik 1 EUR $=6,55957$ FRF (frank francuski),

- Włochy: ze względu na niestabilną wówczas sytuację ekonomiczną kraj ten zmuszony był do zastosowania następującego przelicznika: 1 EUR odpowiadało wartości 1936,27 LTL (lir włoski).

2. Zainicjowanie działań organizacyjnych rozpoczynających proces wymiany:

- Niemcy: Przygotowania rozpoczęto w 1995 roku, kiedy rząd niemiecki zdecydował się powołać specjalną komisję roboczą do spraw unii gospodarczej i walutowej. Zadaniem powołanej grupy było koncentrowanie się na przygotowaniu odpowiednich zmian legislacyjnych. Z kolei Bank Niemiec od samego początku miał się skupić na organizacji i koordynacji całego procesu zastępowania dotychczasowej waluty.

- Francja: Proces wymiany został rozpoczęty pod koniec XX wieku i był koordynowany przez Narodowy Komitet do spraw Euro. Jego celem było przygotowanie odpowiednich zmian w prawie oraz nadzorowanie całego przedsięwzięcia. Oprócz tego została powołana Grupa Koordynacyjna do spraw Wymiany na Euro, na czele której stanął zastępca gubernatora Banku Francji. Prace tych grup były wspierane przez Komitet Sterujący do spraw Euro, który zrzeszał Bank Francji oraz Francuskie Stowarzyszenie Instytucji Kredytowych i Firm Inwestycyjnych. Niektóre banki miały problem ze zrozumieniem stworzonych przez tamtejszego mocodawcę przepisów krajowych - w szczególności dotyczących nowych uprawnień i obowiązków Ministerstwa Finansów, Mennicy i Banku Francji.

- Włochy: Podobnie jak w przypadku Francji rząd włoski powołał do życia Komitet Narodowy do spraw Euro. Jego skład był następujący: przedsta- 
wicielstwo Ministerstwa Gospodarki i Finansów, reprezentanci rządu, Banku Włoch, Włoskiego Stowarzyszenia Bankowego oraz osób związanych z biznesem (na przykład właściciele największych przedsiębiorstw).

3. Opracowanie i przeprowadzenie kampanii informacyjnej:

- Niemcy: Za proces informacyjny społeczeństwa odpowiedzialny był Bank Niemiec. Początkowo przygotował on i opublikował na swoich stronach internetowych broszury informacyjne. Po ujawnieniu przez EBC zabezpieczeń nowej waluty rozpoczął się proces informowania społeczeństwa na temat sposobów weryfikacji jej autentyczności. W celu dotarcia do jak największej liczby osób zorganizowano specjalną kampanię, podczas której odwiedzono 100 miast. Niezbędne było również przeszkolenie pracowników sektora bankowego i handlowego, aby zminimalizować ryzyko wprowadzenia falsyfikatów do legalnego obiegu. W celu lepszego informowania społeczeństwa uruchomiona została specjalna infolinia. Intensywne działania spowodowały, że $62 \%$ społeczeństwa z początkiem XXI wieku wyrażało pozytywną opinię o euro.

- Francja: Na początku 2001 roku rozpoczęta została przez Ministerstwo Gospodarki, Finansów i Przemysłu wraz z Bankiem Francji kampania informacyjna na temat wdrożenia procesu wymiany waluty oraz jej wyglądu i sposobów weryfikacji jej autentyczności. Obejmowała swoim zasięgiem prasę, radio, internet oraz telewizję. Oprócz tego Bank Francji przygotował informacje na temat wyglądu i zabezpieczeń nowych monet i banknotów. Poparcie społeczeństwa do końca 2002 roku wynosiło $75 \%$.

- Włochy: Kampania informacyjna przeprowadzona w tym kraju była procesem angażującym największą liczbę spośród wymienionych wcześniej instytucji. Przeprowadzenie tego procesu spoczywało na: Ministerstwie Skarbu, Komitecie Narodowym do spraw Euro, Banku Włoch, Włoskim Stowarzyszeniu Bankowym oraz Instytucie Studiów do spraw Dóbr Konsumpcyjnych. Zaangażowany został również rząd, który rozesłał do wszystkich gospodarstw domowych kalkulatory umożliwiające sprawne przeliczanie kwot na euro. Po ujawnieniu informacji na temat zabezpieczeń oraz wyglądu nowych monet i banknotów zostały zintensyfikowane działania informacyjne. Wykorzystano do tego celu zostały środki masowego przekazu, takie jak: telewizja, radio, prasa. Poparcie w 2002 roku dla euro wyrażało $76 \%$ mieszkańców.

4. Uzyskanie niezbędnych pozwoleń i rozpoczęcie produkcji nowej waluty:

- Niemcy: Proces druku banknotów rozpoczął się w trzecim kwartale 1999 roku w kilku miejscach: Drukarni Federalnej Niemiec z siedzibą w Berlinie, firmie Giesecke \& Devrient mającej swoje oddziały w Monachium i Lipsku. Za bicie monet odpowiedzialnych było kilkanaście mennic w: Berlinie, Monachium, Stuttgarcie, Karlsruhe i Hamburgu. Do końca 2001 roku wydruko- 
wano 4,7 mld sztuk banknotów (co stanowiło 32\% całej produkcji w krajach UGW) oraz wybito 17 mld sztuk monet (33\% całej produkcji).

- Francja: Do stycznia 2002 roku Bank Francji wyprodukował 2 mld sztuk banknotów (15,2\% całej produkcji w krajach wspólnoty walutowej). Mennica paryska wybiła natomiast 8 mld sztuk monet (15,8\% całej produkcji).

- Włochy: W proces produkcji zaangażowane były dwa podmioty - Bank Włoski oraz mennica rzymska. Wyprodukowano tam do końca 2001 roku 2,4 mld sztuk banknotów oraz 7,9 mld monet. Udział Włoch w budowaniu UGW wyniósł $16,4 \%$ dla banknotów i 15,4\% dla monet.

5. Proces stopniowego zaopatrzenia instytucji oraz społeczeństwa w nową walutę:

- Niemcy: Oprócz produkcji pieniędzy na potrzeby bieżące (punkt 3) niezbędne było wyposażenie wielu instytucji znacznie wcześniej. Proces ten rozpoczął się w trzecim kwartale 2001 roku. Ogółem do instytucji finansowych odpowiedzialnych za zaopatrzenie handlowców (zaopatrzenie wtórne) przekazano banknoty o wartości 57 mld euro oraz 12 mld sztuk monet. Ze względu na ciekawość społeczeństwa wyprodukowano również przed 2002 rokiem 53,5 mln zestawów startowych zawierających monety o wartości 10,23 EUR. W procesie zaopatrzenia społeczeństwa wykorzystane zostały bankomaty, banki oraz detaliści.

- Francja: Dostawy do instytucji finansowych monet i banknotów realizowane były w trzecim kwartale 2001 roku. Dystrybucja prowadzona była z wykorzystaniem konwojów. W całym procesie zaobserwowano znaczne opóźnienia w zaopatrzeniu. Dopiero w styczniu udało się zrealizować plan całkowicie. Problemem okazał się czas niezbędny do stworzenia procedur umożliwiających stworzenie większej liczby centrów dystrybucyjnych, ponieważ obecnie istniejące nie były przygotowane na taką liczbę monet, których na te cele zostało wyprodukowanych łącznie 6,7 mld sztuk. Również tutaj przygotowano $53 \mathrm{mln}$ zestawów startowych o wartości 15,25 EUR, jednakże ze względu na wady technologiczne ich sprzedaż rozpoczęła się w styczniu 2002 roku zamiast w grudniu 2001 roku. Wywołało to ogólne niezadowolenie społeczeństwa. Dodatkowo niechęć sektora bankowego do sprzedaży starterów spowodowała, że około $13 \mathrm{mln}$ z $53 \mathrm{mln}$ nie zostało sprzedanych. Ich wypakowanie i przekazanie do obrotu było procesem kosztownym. Wprowadzenie euro do obiegu było możliwe dzięki wykorzystaniu bankomatów, banków komercyjnych, automatów wrzutowych oraz dzięki sektorowi detalicznemu.

- Włochy: Zaopatrzenie instytucji finansowych i urzędów pocztowych rozpoczęło się we wrześniu i listopadzie. Powyższe instytucje otrzymały łącznie banknoty o wartości 21 mld EUR oraz monety w liczbie 6 mld sztuk. 15 grudnia 2001 roku udostępniono $30 \mathrm{mln}$ zestawów startowych zawiera- 
jących monety o wartości 12,91 EUR. Ich sprzedaż odbywała się głównie w bankach. Zaopatrzenie społeczeństwa zostało zintensyfikowane poprzez umożliwienie wypłat nowej waluty w bankomatach, bankach, urzędach pocztowych oraz zobowiązanie sektora detalicznego do wydawania reszty w nowej walucie.

6. Przygotowanie sektora bankowego i handlowego do obsługi nowej waluty:

- Niemcy: Operacja przewalutowania rachunków bankowych rozpoczęła się w październiku 2001 roku. Według szacunków procesowi temu poddanych zostało $400 \mathrm{mln}$ kont. Proces przebiegł bez większych zakłóceń.

- Francja: Konwersja rachunków rozpoczęła się już z początkiem 2001 roku. W przypadku rachunków bieżących klientów proces ten ruszył w lipcu 2001 roku. Wystąpiły pewne problemy w obszarze płatności kartami, gdyż operatorzy systemów nie nadążali z dostosowywaniem swoich systemów do nowej waluty, co spowodowało liczne błędy i konieczność częstych interwencji ze strony banków w celu wprowadzenia właściwej waluty użytej w transakcjach.

- Włochy: Początkowo niewielki odsetek klientów zdecydował się dobrowolnie przewalutować swoje rachunki. Pod koniec 2001 roku przeprowadzono masową konwersję ze względu na upływający termin okresu przejściowego. Nie odnotowano większych problemów, brak jest też informacji na temat kont poddanych temu procesowi. Terminale płatnicze zostały przystosowane do obsługi nowej waluty w pierwszych tygodniach 2002 roku.

7. Okres podwójnego obiegu walut:

- Niemcy: Rodzima waluta straciła status prawnego środka płatniczego w nocy z 31 grudnia na 1 stycznia 2002 roku. Ze względu na brak rozwiązań wprowadzonych przez rząd przedstawiciele sektora bankowego sporządzili w 1998 roku deklarację o akceptacji marek niemieckich. Takie działanie umożliwiło niezaburzone funkcjonowanie używanych dotychczasowo monet i banknotów do 28 lutego 2002 roku. Proces zastępowania waluty odbył się sprawnie i już 4 stycznia według szacunków 50-65\% transakcji realizowanych było w euro.

- Francja: Euro oficjalnie zastąpiło franka francuskiego 1 stycznia 2002 roku w transakcjach bezgotówkowych, a 17 stycznia tego roku frank przestał być prawnym środkiem płatniczym. Proces wymiany nie przebiegał tak sprawnie, jak w przypadku Niemiec, jednakże udało się go sfinalizować z końcem stycznia, a więc na co najmniej 2 tygodnie przed wejściem w życie nowych regulacji prawnych.

- Włochy: Do 28 lutego 2002 roku lir włoski i euro posiadały status prawnych środków płatniczych. Z dniem 1 marca 2002 roku nowe banknoty i monety stały się jedynym dopuszczalnym środkiem płatniczym. Tempo przejścia na walutę europejską było wolniejsze w porównaniu do innych państw 
UGW ze względu na masowe wypłaty starej waluty przez społeczeństwo, co wpłynęło na zwiększenie zapasów waluty podlegającej wymianie. Od końca stycznia 2002 roku ponad 90\% transakcji przeprowadzanych było w euro.

8. Wycofanie waluty narodowej z obiegu i zastąpienie jej walutą wspólnoty:

- Niemcy: W momencie nabycia mocy prawnej przez nową walutę Bank Niemiec zdecydował się na bezterminowe świadczenie usługi wymiany marki niemieckiej na euro. Do grudnia 2001 roku wartość niemieckich marek znajdujących się w obiegu spadła ze 142 mld EUR do 31 mld EUR. Szacuje się, że około $2 \%$ banknotów, głównie o niskich nominałach, nigdy nie zostanie zwrócona.

- Francja: Po 17 lutym 2002 roku, a więc po utraceniu obowiązującej mocy prawnej, Bank Francji świadczył usługi wymiany franków francuskich do 2005 roku w przypadku monet oraz do 2012 roku dla banknotów. Wszystkie banki uzyskały pozwolenie na niszczenie banknotów poprzez ich dziurawienie. Podczas tego procesu wystąpiło kilka komplikacji dotyczących nadmiernej i nieprzewidzianej ilości zwracanych monet. Skutkiem tego było utracenie płynności w przeliczaniu i dostarczaniu monet do Banku Francji w celu wymiany ich na odpowiednią ilość euro. Spowodowało to wielomilionowe straty w sektorze bankowym.

- Włochy: Wymiana waluty realizowana była przez Bank Włoch, banki komercyjne oraz urzędy pocztowe. Bezpłatna wymiana możliwa była do 2012 roku. Wszystkie instytucje na mocy obowiązującego prawa zostały zaopatrzone w przyrządy znakujące zwracane banknoty, które następnie były przekazywane do banku centralnego w celu zniszczenia.

\section{Podsumowanie}

Integracja na płaszczyźnie walutowej 19 spośród 28 obecnych w Unii Europejskiej krajów członkowskich bez wątpienia wpłynęła na zacieśnienie relacji między nimi. Stworzenie przy tym jednej organizacji mającej charakter ponadnarodowy i znanej dziś pod nazwą Europejski Bank Centralny spowodowało, w ocenie autora, równe traktowanie państw należących do III etapu unii gospodarczej i walutowej. Używanie wspólnej waluty niweluje różnice ekonomiczne w społeczeństwie ze względu na realizację celów kluczowych z punktu widzenia całej UGW bez faworyzowania najsilniejszych gospodarek ani wykluczania słabszych. Niewątpliwie wpływa również na usprawnienie transakcji międzynarodowych pomiędzy 19 krajami ze względu na brak konieczności przeliczania walut. W końcu wpływa na tak mocną integrację, że dzięki temu można mówić o gospodarce europejskiej czy też walucie posiadającej silną pozycję w dzisiejszym świecie. Starania wielu wybitnych osób tamtejszej, jak i obecnej sceny doprowadziły do tego, że strefa euro jest jedną z największych po- 
tęg gospodarczych, a jej waluta zajmuje drugie miejsce w obrocie, stanowiąc jedną z kluczowych walut rezerwowych trzymanych przez banki centralne wielu państw (Strefa euro na tle świata, 2019). Analizując kroki podjęte przez trzy największe gospodarki UGW (Francja, Niemcy, Włochy), można zauważyć, jak dużym przedsięwzięciem jest proces zastępowania waluty. W wielu przypadkach wywołał on niepożądane i chwilowe anomalie, takie jak efekt cappuccino polegający na wzroście cen dóbr często kupowanych, których cena przed zmianą waluty była stosunkowo niska. Nazwa wzięła się z Włoch, gdzie sprzedawcy kawy w celu przyspieszenia dokonywanych transakcji zaokrąglali ceny, czego skutkiem był wzrost ceny tego napoju o blisko 30\%. Podobnie sytuacja wyglądała we Francji, gdzie nastąpiły spore podwyżki w sektorze piekarniczym (Rożek, 2009).

\section{Bibliografia}

Banknotes and coins circulation, https://www.ecb.europa.eu/stats/policy and exchange rates/banknotes+coins/circulation/html/index.en.html [dostęp: 18.03.2020].

Barcz J. (2009), Instytucjonalne uwarunkowania rozszerzenia Unii Europejskiej, https://repozytorium.amu.edu.pl/bitstream/10593/4880/1/05_Jan_Barcz Instytucjonalne \%20uwarunkowania $\% 20$ strategii $\% 20$ rozszerzenia $\% 20$ Unii\%20Europejskiej_87-110.pdf [dostęp: 18.03.2020].

Breński W. (2013), Mini Leksykon Encyklopedyczny Unii Europejskiej, https://wsge. edu.pl/pl/13 pub09caly.pdf [dostęp: 18.03.2020].

Ciszak T., Górska A., Otachel B., Siemaszko M., Żak R., Żogała M. (2004), Europejski System Banków Centralnych, https://www.nbp.pl/publikacje/esbc/esbc. pdf [dostęp: 18.03.2020].

European Classification of Individual Consumption according to Purpose (ECOICOP),

Eurostat, https://ec.europa.eu/eurostat/ramon/nomenclatures/index.cfm?TargetUrl=LST CLS DLD\&StrLanguageCode=EN\&StrNom=COICOP 5\&StrLayoutCode=HIERARCHIC\# [dostęp: 18.03.2020].

Gajewski R., Pilichowska K. (2016), Wpływ kursów walut i ich systemów na sytuację firm transportowych eksportujacych swoje ustugi na rynek europejski, http:// dspace.uni.lodz.pl/xmlui/bitstream/handle/11089/22691/\%5B201\%5D-213 Gajewski_Wpływ\%20kursów\%20walut.pdf?sequence $=1 \&$ is Allowed $=\mathrm{y}$ [dostęp: 18.03.2020].

Grabia T. (2007), Wpływ inflacji na poziom życia i nierówności społeczne, http://ur.edu. pl/pliki/Zeszyt11/41.pdf [dostęp: 18.03.2020].

Gross domestic product at market prices (2018), Eurostat, https://ec.europa.eu/eurostat/ databrowser/view/tec00001/default/table?lang=en [dostęp: 18.03.2020].

Grycuk A., Russel P. (2017), Członkostwo w Unii Europejskiej a rozwój gospodarczy Polski, http://orka.sejm.gov.pl/wydbas.nsf/0/06EED08BF358EEB4C12581B- 
60038F 894/\%24File/4\%20Adrian\%20Grycuk\%20Piotr\%20Russel\%20 Członkostwo\%20w\%20Unii\%20Europejskiej\%20a\%20rozwój\%20gospodarczy \%20Polski\%20Studia\%20BAS\%20nr\%203\%202017.pdf [dostęp: 18.03.2020].

Gwóźdź-Lasoń M., Miklaszewicz S., Pujer K. (2017), Unia Europejska i strefa euro. Doświadczenia i wyzwania ekonomiczne, techniczne i inżynieryjne, https:// depot.ceon.pl/bitstream/handle/123456789/12068/Unia_Europejska_strefa_euro 1p.pdf? sequence=1\&isAllowed=y [dostęp: 18.03.2020].

Historia: Europejska Wspólnota Obronna (2011), https://multimedia.europarl.europa.eu/ pl/history-european-defence-community V001-0010 ev [dostęp: 18.03.2020].

Kołek P. (2011), Unia Beneluksu - nowa odsłona starej współpracy, https://www. academia.edu/36270378/Unia_Beneluksu_-_nowa_odsłona_starej_współpracy The Benelux Union_a new version of the old cooperation [dostęp: 18.03.2020].

Krzemień K. (2018), Pieniądz fiducjarny - daj wiare walucie https://goldenmark. com/pl/mysaver/pieniadz-fiducjarny/ [dostęp: 8.03.2020].

Madej K. (2007), Plan Marshalla, http:/www.polska1918-89.pl/pdf/plan-marshalla,5420.pdf [dostęp: 18.03.2020].

Mikita M. (2016), Międzynarodowy system walutowy przyszłości, http://cejsh.icm.edu.pl/ cejsh/element/bwmeta1.element.hdl_11320_4468/c/79 Optimum_1_2016 Mikita.pdf [dostęp: 18.03.2020].

Orłowski W. (2015), Luzowanie ilościowe: czym jest, do czego służy?, https://www. polityka.pl/tygodnikpolityka/rynek/edukatorekonomiczny/1643105,1,luzowanie-ilosciowe-czym-jest-do-czego-sluzy.read [dostęp: 18.03.2020].

Pabis K. (2013), Historia Unii Europejskiej, http://rep.up.krakow.pl/xmlui/bitstream/handle/11716/1527/01--Historia-Unii-Europejskiej--Pabis.pdf?sequence=1\&isAllowed=y [dostęp: 18.03.2020].

Parlament Europejski (2019), Rozszerzenie Unii Europejskiej, http://www.europarl. europa.eu/ftu/pdf/pl/FTU 5.5.1.pdf [dostęp: 18.03.2020].

Piński J. (2016), Czym naprawdę jest atak spekulacyjny?, https://archiwum.gf24.pl/ czym-naprawde-jest-atak-spekulacyjny/ [dostęp: 18.03.2020].

Przebieg procesu wprowadzania banknotów i monet euro w państwach unii gospodarczej $i$ walutowej (2003), Narodowy Bank Polski, https://www.nbp.pl/publikacje/o_euro/wprowadzenie euro.pdf [dostęp: 18.03.2020].

Rożek T. (2009), Efekt cappuccino, czyli urojona drożyzna, https://polskatimes.pl/ efekt-cappuccino-czyli-urojona-drozyzna/ar/155764 [dostęp: 18.03.2020].

Sofuł A. (2009), ERM II, obowiązkowa poczekalnia przed euro, https://www.newsweek.pl/biznes/erm-ii-obowiazkowa-poczekalnia-przed-euro/jzc5nl0 [dostęp: 18.03.2020].

Strefa euro na tle świata (2019), https://www.ecb.europa.eu/explainers/tell-me-more/ html/euro area_in_comparison.pl.html [dostęp: 18.03.2020]. 
Szopa B. (2012), Ewolucja międzynarodowego systemu walutowego i finansowego, http:// www.krakow.pte.pl/pliki/zn-pte-nr-13/zn-13szopa.pdf [dostęp: 18.03.2020].

Traktat z Maastricht i traktat z Amsterdamu (2019), Parlament Europejski, http:// www.europarl.europa.eu/ftu/pdf/pl/FTU 1.1.3.pdf [dostęp: 18.03.2020].

Wyżnikiewicz B. (2017), Produkt krajowy brutto jako przedmiot krytyki, http://cejsh. icm.edu.pl/cejsh/element/bwmeta1.element.desklight-ab9cfc61-797b-463f -aa9e-52333f250ffd/c/WS $03 \quad 2017 \quad 03$ Bohdan WYZNIKIEWICZ Produkt krajowy brutto jako przedmiot krytyki.pdf [dostęp: 18.03.2020].

Żuk P. (2015), Co to jest inflacja?, https://www.nbportal.pl/wiedza/artykuly/finanse/ co-to-jest-inflacja [dostęp: 18.03.2020].

\section{Akty prawne i wyroki}

Deklaracja nr 17 odnosząca się do pierwszeństwa stanowiąca załącznik do traktatu z Lizbony zmieniającego Traktat o Unii Europejskiej i Traktat ustanawiający Wspólnotę Europejską podpisanego w Lizbonie dnia 13 grudnia 2007 r. (Dz. Urz. UE C 326/346 z 26.10.2012 r.).

Konstytucja Rzeczypospolitej Polskiej z dnia 2 kwietnia 1997 r. (Dz. U. 1997, nr 78, poz. 483 z późniejszymi zmianami).

Protokół nr 12 określający procedurę nadmiernego deficytu stanowiący załącznik do Traktatu o funkcjonowaniu Unii Europejskiej (Dz. Urz. UE C 326/279 z 26.10.2012 r.).

Protokół nr 13 w sprawie kryteriów konwergencji stanowiący załącznik do Traktatu o funkcjonowaniu Unii Europejskiej (Dz. Urz. UE C 326/281 z 26.10.2012 r.).

Statut Rady Europy, przyjęty w Londynie dnia 5 maja 1949 r. (Dz. U. 1994, nr 118, poz. 565)

Traktat o Unii Europejskiej przyjęty w Maastricht (Dz. Urz. UE C 326/13 z 26.10.2012 r.). Traktat Północnoatlantycki sporządzony w Waszyngtonie dnia 4 kwietnia 1949 r. (Dz. U. 2000, nr 87, poz. 970).

Traktat z Lizbony zmieniający Traktat o Unii Europejskiej i Traktat ustanawiający Wspólnotę Europejską podpisany w Lizbonie dnia 13 grudnia 2007 r. (Dz. Urz. UE C 306 z 17.12.2007 r.).

Wyrok Trybunału Konstytucyjnego z dnia 11 maja 2005 r., sygn. akt K 18/04 (Dz. U. 2005, nr 86, poz. 744).

Wyrok Trybunału z dnia 15 lipca 1964 r. w sprawie C-6/64 pomiędzy Flaminio Costa a E.N.E.L. 


\section{Summary}

The process of changing the national currency for the euro in countries seeking entry to the third stage of economic and monetary union

This article describes the process of establishing the European Union and the common economic and monetary area by referring to the most important milestones for integration between countries after World War II. Winston Churchill's speech in the late summer of 1946, in which he presented a vision of The United States of Europe, is referred to. At the beginning of the 21st century the euro officially began to replace national currencies. The author explains the current currency convergence criteria and considers the economic concepts necessary to understand the issue. The article concludes with a description of the process of replacing national currencies in the three largest economies in the euro area - Germany, France and Italy. The article contains numerous references to the founding treaties, legal acts of the European Union and judgments of the Tribunals.

Keywords: convergence criteria, economic and monetary Union, change currency, finance 